\title{
Operations of the Federal Reserve Bank of St. Louis - 1974
}

\author{
JEAN LOVATI
}

T HE Federal Reserve System consists of the Board of Govenors, located in Washington, D. C., and twelve Federal Reserve Banks located in districts across the United States. The Federal Reserve Bank of St. Louis serves the Eighth Federal Reserve District which includes all of Arkansas and parts of Illinois, Indiana, Kentucky, Mississippi, Missouri, and Tennessee. To assist in servicing the area, branches of the St. Louis Federal Reserve Bank are located in Little Rock, Louisville, and Memphis.

The St. Louis Federal Reserve Bank and its branches perform a variety of services for the public, commercial banks, and the United States Government. These services include collecting and clearing checks, transferring funds, distributing coin and currency to commercial banks, and conducting fiscal agency operations for the Federal Government. The Bank also extends credit to member banks and supervises certain commercial banks to promote sound banking practices. This report reviews most of the operations and functions of the St. Lotis Federal Reserve Bank and its branches durimg 1974. The actions of the Bank, along with the other eleven Federal Reserve Banks and the Board of Governors, in formulating and implementing monetary policy are discussed in other issues of the Review.

\section{Bank Supervision and Regulation}

The Federal Reserve Bank of St. Louis, along with the state banking authorities, supervises state chartered member banks in the Eighth Federal Reserve District. Bank supervision encompasses a wide variety of technical functions relating to the operntions of member banks. The Bank Supervision and Regulation Department oversees the admission of state banks into the Federal Reserve System, conducts annual bank examinations, and analyzes periodic reports of condition. It reviews proposed mergers resulting in state member banks and applications to open new branches by these banks.

The most familiar form of supervisory activity is bank examination, through which information is collected on the current financial condition of individual banks. The examiners ascertain whether state nember banks are complying with the applicable laws and regulations and evaluate each bank's assets, liabilities, capital, liquidity, operations, and management.
The 88 state member banks in the Eighth District were examined by St. Louis Federal Reserve Bank examiners in 1974. These banks are also subject to examination by state banking authorities. The 343 national banks in the Eighth District, which are required by law to be members of the Federal Reserve System, are examined by the staft of the Comptroller of the Currency. State nommember banks that are insured by the Federal Deposit Insurance Corporation (FDIC) are examined by the FDIC along with the respective state banking authorities. The noninsured banks in the District are examined by state examiners only.

Federal Reserve Banks also supervise bank holding companies. At the end of 1974, the Federal Reserve Bank of St. Louis had jurisdiction over 17 multibank holding companies and 73 one-bank holding companies. The Bank Supervision and Regulation Department, with the assistance of the Legal and Research Departments, analyzes applications for bank holding company formations and holding company acquisitions of additional banks and firms in industries closely related to banking. In reviewing an application, these departments consider the financial history, conditions, and prospects of the institutions involved, and evaluate the quality of management. The legal aspects of the proposal and its likely effects on banking competition are assessed. During 1974, this Bank processed 11 applications to form one-bank or multibank holding companies and 39 applications by holding companies to acquire additional subsidiaries.

Bank holding companies are required to file annual reports with the Reserve Banks. These annual reports are analyzed by the staff of the Bank Supervision and Regulation Department to verify accuracy and completeness, to ascertain the financial conditions of the holding company and its subsidiaries, and to determine compliance with applicable laws and regulations. Examination reports submitted to the primary supervisory agency of the respective bank subsidiaries are also analyzed by the Federal Reserve Bank to determine the overall conditions of such sub. sidiaries. In addition, the Bank conducts discretionary on-site inspections of bank holding companies. The purpose of these inspections is similar to that of examinations of subsidiary banks. 


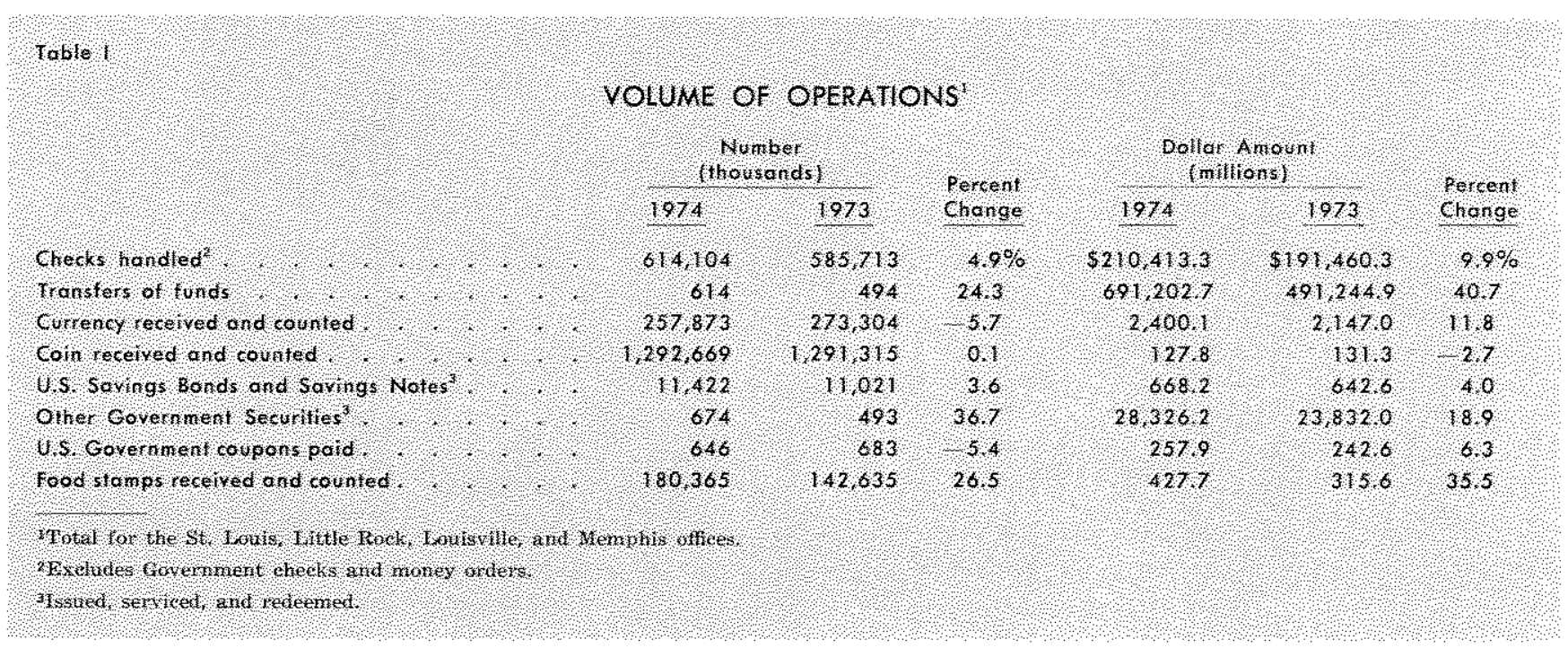

\section{Check Collection}

Checks drawn on commercial banks are the major means of settling daily financial transactions, since in most cases payment by check is more convenient than payment by currency. The use of checks is facilitated by the collection and clearing operations of the Fedexal Reserve Banks, which provide a mechanism for settlement of checks collected by commercial banks. Settlement is made by entries to the reserve accounts of member banks.

Since the number of checks cleared has increased rapidly in recent years, the Federal Reserve System has instituted a method to improve the handling. clearing, and settling of checks and to increase the speed of the payments mechanism. Regional Check Processing Centers (RCPCs) have been established in key cities across the country for these purposes. RCPCs are facilities which serve a geographic area wherein checks drawn on participating banks are processed ovemight.

The Federal Reserve Bank of St. Louis and its branches each have been defined as an RCPC. A zone has been established for each center which corresponds to that portion of the Eighth District served by the respective offices. Overnight check clearing within the zones has been expanded since 1972 to include additional counties, thus providing more banks with this faster service. The RCPC zones of the Menphis and Louisville branches have already been expanded to cover the entire areas served by these offices. Approximately 90 percent of the dollar volume of checks in the Little Rock zone and 80 percent of the dollar volume in the St. Louis zone are on an immediate payment basis.
The four Eighth District Federal Reserve offices cleared 614 million checks with a dollar volume of $\$ 210$ billion in 1974 . This represents a 4.9 percent increase in number and a 9.9 percent increase in dollar volume over 1973 (See Table I).

\section{Electronic Transfer of Funds}

In order to further increase the efficiency and speed at which funds are transferred, the Federal Reserve Bank of St. Louis is expanding its part of the Federal Reserve Communications System. A computer at the Bank serves as the communication and switching center for the entire Eighth District. Member banks may use the System's network to transfer to other nember banks funds of $\$ 1,000$ or more for their own accounts, or for their customers, anywhere in the country without charge. These transfers are most often used for large transactions and for those requiring immediate payment. Nonmember banks have access to this service indirectly through member banks.

Significant changes in the structure of the communication network in the Eighth District were implemented in 1974. Recently, on-line terminals were installed at the three St. Louis commercial banks having the largest volume of funds transferred through the St. Louis Federal Reserve Bank. These terminals are linked directly to the Bank's computer and enable the banks to initiate fund transfers directly from their offices. Previously, banks usually telephoned or teletyped the necessary information to the St. Louis Federal Reserve Bank for transmission. Now a transfer initiated by means of an on-line terminal is switched automatically by computer through the Federal Reserve Bank of St. Louis to the Federal Reserve office 
of the receiving commercial bank with no direct involvement by personnel at the St. Louis Federal Reserve Bank. If the receiving bank is also on-line, the transfer is again automatically switched by computer to that bank through its Federal Reserve office without being handled by the persomel at that office.

As the fund transfers are processed, the computer generates the accounting data and other information needed to complete the transaction. This information is then used to update member banks' reserve accounts. Banks with on-line terminals receive an immediate record of each transaction.

Three commercial banks in St. Louis and two commercial banks in Memphis plus the St. Louts, Lotisville, and Memphis Federal Reserve oflices are now ondine to the Bank's computer. A funds transaction may require as long as 2-3 hours for completion when information is telephoned or teletyped to the Federal Reserve Bank. Automated switching Kas reduced that time to 2-3 minutes, and has reduced the number of transfers handled by the Bank's personnel by 70 percent. An average of 937 transactions per day sent and received are no longer handled by the personnel of the Federal Reserve Bank of St. Louis since the in stallation of on-line teminals at the three St. Louis commercial banks.

The Federal Reserve Bank of St. Louis facilitated the transfer of more than $\$ 290$ billion of funds in 1974. This reptesents a 26 percent increase from the $\$ 231$ billion transferred in 1973. During 1975, the Little Rock branch and nine additional large volume banks in the Eighth District are expected to be directly linked to the computer facilities at the St. Louis Federal Reserve Bank through on-line teminals.

\section{Coin and Currency}

Although checks and wire transfers are the major means of payment in this country in terms of dollar volume, coin and paper currency are indispensible and are used in the greatest number of transactions. Currency is more widely acceptable than checks and is a more convenient means of settling relatively small transactions. To meet the public's demand for cash, a member bank orders currency from its Federal Reserve Bank, which charges the order to the member's reserve account. On the other hand, if a member bank has excess currency, it may deposit currency at the Federal Reserve Bank and receive credit in its reserve account. Nonmember banks generally receive or deposit coin and currency through member banks. Currency is sorted at the Reserve Banks and that which is no longer usable is removed from circulation and destroyed. During 1974, currency totalling $\$ 809$ million was verified and destroyed.

Combined sorting, counting, and wrapping of coin and currency at all four Reserve Bank offecs in the Eighth District amounted to slightly less than 7.6 million pieces per working day during 1974. This vol ume represents a decrease of 13 percent compared to 1973.

\section{Lending}

Fedenal Reserve credit is extended on a short term basis to member banks which intend to use this source of credit to meet their reserve requirements. There are three types of credit available to members from thein Federal Reserve Banks: short-term adjustment credit, seasonal credit, and mergency credit. The interest rate at which these banks may borrow is called the discount rate. During periods when short-term market interest rates are lower than the discount rate, member banks may be reluctant to borrow from the Federal Reserve to cover temporary adjustment needs. Instead, they may obtain funds through the Federal fumbs market (where one commercial bank lends to another) or through the markets for other short-term instruments. On the other hand, if the discotnt rate is low relative to rates in these markets, Federal Reserve lending is likely to increase.

An amendment to Regulation $A$ of the Federal Re* serve Act was approved in 1974. This amendment authorizes the application of a special discount rate to certain types of lending to member banks. The special rate applies to Federal Reserve credit to member banks requesting large assistance over a prolonged period where there ate exceptional circumstances involving only a particular member bank. The special rate would ordinarily be higher than the discount rate.

The discount rate at the beginning of 1974 was 7.5 percent. It was raised one time to a record 8 percent on April 26, and then lowered once to 7.75 percent on December 13. Short-term market interest rates remaned above the discount rate throughout 1974 .

The St. Louis Federal Reserve Bank made 2,164 advances totalling $\$ 11.1$ billion to 111 Eighth District member banks in 1974. During the previous year, 1,759 advances totalling $\$ 11.1$ billion were made to 95 member banks. The daily average of outstanding loans was roughly the same in 1974 and $1973, \$ 54.9$ million. 
The Fedenal Reserve Banks extend credit to smaller banks to tide these banks over peak seasonal demands for funds. Nine banks in the Eighth District made use of this seasonal borrowing privilege during 1974. All of the banks which used this privilege were located in predominantly agricultural areas. No emer. gency loans were granted.

\section{Tischil Agench}

The Federal Reserve Bank provides a number of services as a fiscal agent of the Federal Government. As banker for the Government, the Reserve Banks carry the principal checking accounts of the United States Treasury through which the Covernment rew ceives and spends its funds. Govermment receipts come mainly from taxpayers and purchasers of Federal Government securities, and are deposited initially in Treasury tax and loan accounts at designated com mercial banks. Periodically, these funds are transferred to Treasury accounts at the Federal Reserve Banks and spent.

The Reserve Banks also act as an agent for the Government in issuing and retining Federal Goveram ment securities. When the Treasury offers new securities, the Reserve Banks publicize the sale and receive bids from banks, dealers, and others who wish to buy. In accordance with instructions from the Treasury, allotments of securties are made by the Reserve Banks which collect payment on the Govermment's behalf. After the securities have been issued and delivered, the Reserve Banks pay the interest on the securities and redeem them at maturity with funds from the Government's account.

In 1974, 11.4 million savings bonds and notes and 674,000 other Treasury issues with a combined dollar value of roughly $\$ 29$ billion were issued, serviced or redeemed by the four Eighth District Federal Reserve offices. During the year, 646,000 Government bond coupons valued at $\$ 257.9$ million were paid by these offices.

Another fiscal activity is the redemption of U.S Govemment food stamps. A total of 180 million food stamps with a value of $\$ 428$ million were received and counted by the Federal Reserve Bank of St. Louis and its branches in 1974 .

\section{Peseanctiv}

The Research Department contributes to national monetary policy through its collection and analyses of a wide range of regional, national, and interna- tional economic data. The intomation is used by the President of the Bank in making monetary policy recommendations at meetings of the Federal Open Market Committee. This Committee, which consists of the Board of Governors and five of the twelve Reserve Bank Presidents, directs the purchase and sale of Treasury and Govermment Agency securities on the open market by the Federal Reserve System. The economic analyses of the Reseatch Department are also useful to the Bank's Board of Directors in establishing, subject to approvat by the Board of Governors, the Bank's discount rate.

The public aso has access to data and information relating to economic developments through the Research Department's 10 regula publications. The Review, with a monthly circulation of 35,000, incorporates much of the analytical research done by the Research staft, Research staff members are encouraged to publish studies in professional journals as well.

In addition to these functions, the Research Department engages in studies of bank market structure. These studies include review and analysis of proposed bank holding company acquisitions and bank mergers. In this analysis, consideration is given to the expected effects of the proposed acquisitions and mergers on competition and on the convenience and needs of the area to be served.

\section{Bank Relations and Public Infomation}

The St. Louis Federal Reserve Bank endeavors to mantain personal contact with all banks in the Eighth District and aids member banks in their actions dealing with the Federal Reserve. The Bank Relations and Public Infomation Department makes avalable to all Eighth District member banks the Federal Reserve Functional Cost Analysis Program which provides a cost-income profile of the participating bank's major functions. The individual bank can compare its current operating costs and revenue for individual services not only with its past performance but also with average figures for member banks of similar size. There were 46 banks participating in the program last year in the Eighth District.

Through this department, the Bank also maintains contact with the public. Officers and staft members of the St. Louis Federal Reserve Bank and its branches presented 227 addresses before groups of bankers, businessmen, and educators in 1974. The Bank was represented at 314 banker, 151 professional, and 225 miscellaneous meetings. During the year, 235 groups 


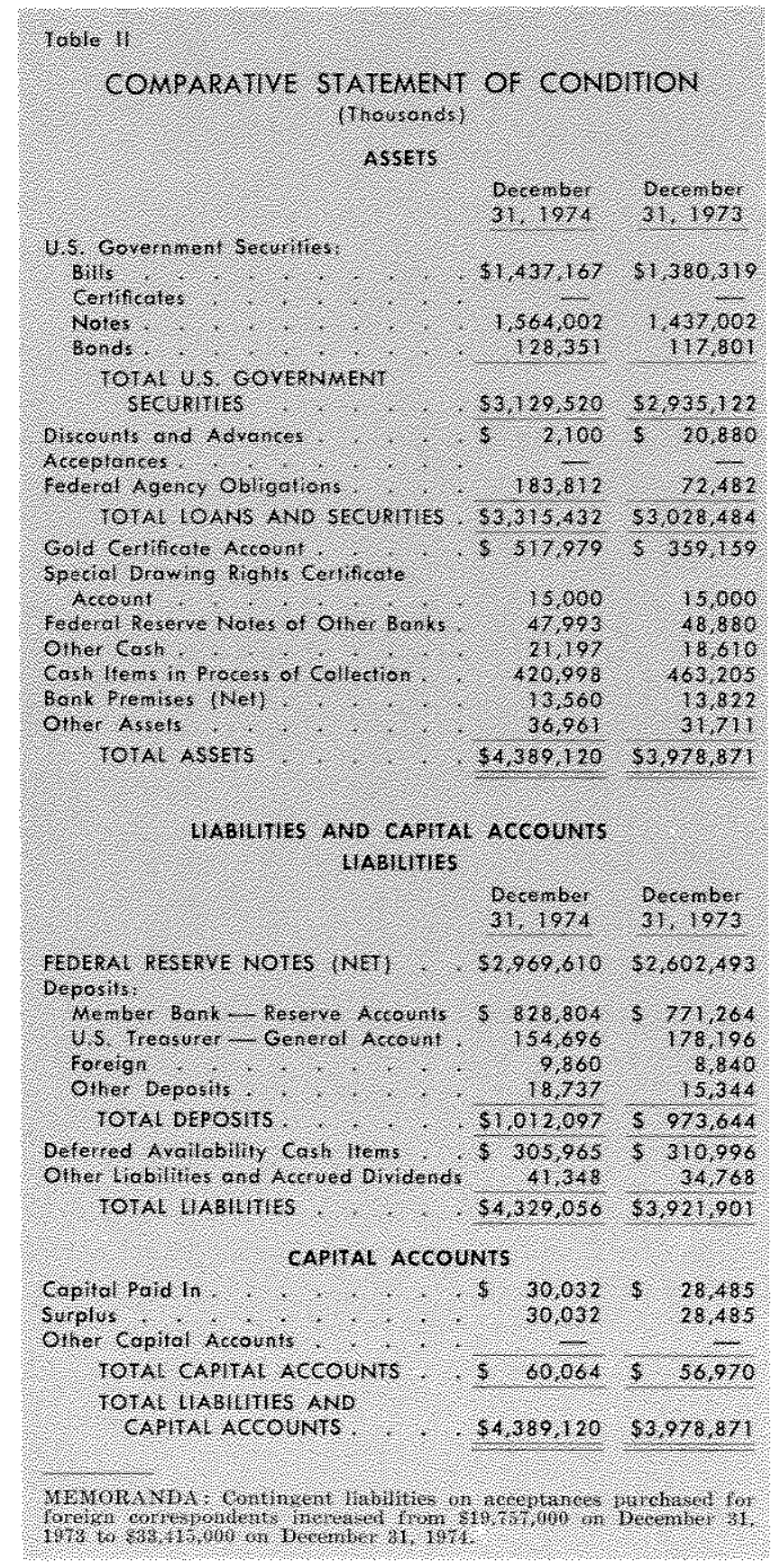

requested films, and 3,802 visitors toured the Bank and its branches. The Bank's traveling currency exhibits were displayed at ten banks during 1974.

\section{Financial Statements}

Total assets of the Federal Reserve Bank of St. Lovis and its branches at the end of 1974 were $\$ 4.4$ billion, an increase of 10.3 percent from the previous year (see Table II). A \$11 million increalse in Federal Agency obligations and a $\$ 159$ million increase in the Gold Certificate Account were the major sources of the increase in total assets. Approximately 71 percent of the Bank's assets were held in U.S. Government securities. The remaining assets, incluhing the gold certificate acount, the special drawing riglts certificate account, notes on other Reserve Banks, and cash items in process of collectim totalled $\$ 1.3$ billion.

Liabilities of the St. Louis Federal Reserve Bank and its branches increased 10.4 percent over the 1973 level, to $\$ 4.3$ billon. This increase primarily resulted from a 14.1 percent increase in Federal Reserve Notes, the principle type of currency in circulation. These notes amounted to $\$ 3.0$ billion, approximately 69 percent of the Bank's total liabilities at year end 1974. Deposits, consisting mainly of member bank reserve accounts, amounted to $\$ 1.0$ billion, an increase of 4.0 percent.

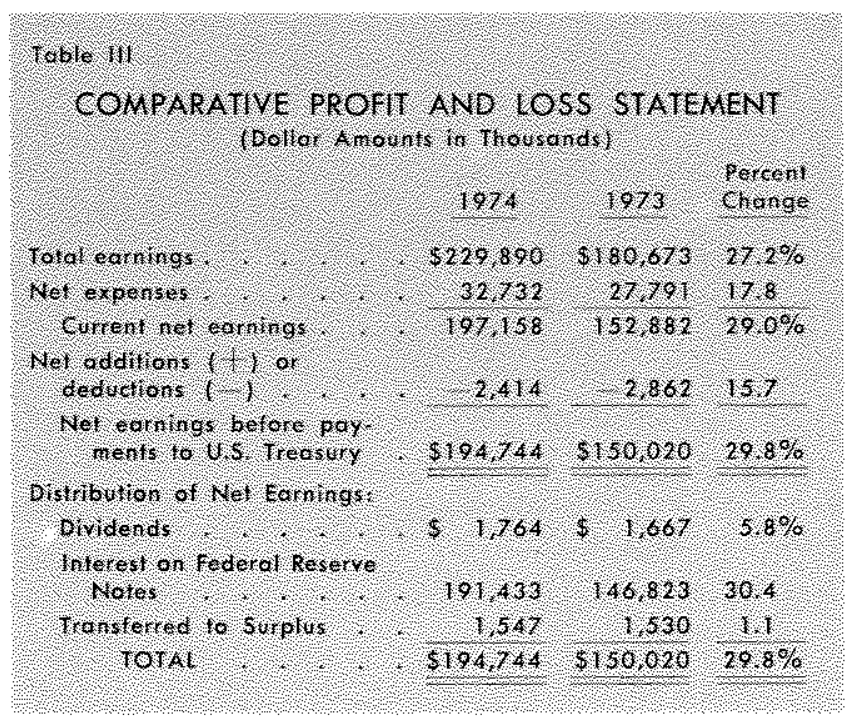

Federal Reserve Banks' earnings result from interest on Govermment securities, interest on loans to member banks, and reimbursements of certain fiscal agency functions. In 1974, the portion of the Federal Reserve System's earnings allocated to the St. Louis Bank and its branches totalled $\$ 230$ million, an increase of 27.2 percent from the previous year (see Table III). After statutory dividends of $\$ 1.7$ million were paid to member banks and operating expenses of $\$ 32.7$ million were covered, $\$ 1.5$ million was transferred to surplus and $\$ 191$ million was paid to the Treasury as interest on Federal Reserve notes. 